\title{
' $O$ worship the Lord in the beauty of holiness: let the whole earth tremble before him' (Psalm 96:9)
}

\section{Ron Nicolson \\ Nicolson@ukzn.ac.za}

\section{Abstract}

My main question in this article is: Is there a place and a future for persons who still hold to the centrality of Christ, or of Jesus of Nazareth, in their lives, but who are agnostic about what traditional Christianity would hold to be central points of dogma or even about the existence of what Cupitt and others have called an 'objective God'? My view is that the liberal theology which dominated the 1950s and 1960s has given way to more conservative and indeed near fundamentalist views in both Protestant and Catholic Theology. It is to be noted though, that within both evangelical and catholic circles, there is some evidence of a swing back to more liberal views. Most people in the Western world have however lost any link with the church or with institutional Christianity. Yet, according to polls, a surprising number still claim that they 'pray' and believe in a 'higher power'. Movements such as the Sea of Faith, or Progressive Christianity attempt to hold on to Christian imagery and cultus while leaving open the question of whether the concept of God is any more than a human construction. Attendance at Cathedral-type worship where dignified ceremony and beautiful music leave the worshipper free to place his or her own interpretation on the words is steadily increasing. Given this state of affairs, my question is: Does this signify a new form of religious belief, more fluid and less linked to institutional dogma? Following James Fowler, my view is that the direction that the most mature form of faith, is that which acknowledges ambiguity and unknowableness in religious belief. Robert Ellwood also suggests that the Western post-Christian world is moving unto what he calls the 'folk-religion' stage where persons may follow many different religious beliefs and practices simultaneously in a syncretistic way 


\section{Ron Nicolson}

without believing any of them in a literal sense, or alternatively believing them all, despite difference and incongruity. Is this the future of religion? Is there a future for a type of Christianity which still reads the scriptures, practices the liturgies, tells the stories but does not necessarily believe that Jesus is God incarnate or indeed that there is any God? These are the issues the chapter addresses.

Keywords: agnostic, dogma, God, Liberal Theology, Protestant Theology, Catholic Theology, Sea of Faith, Progressive Christianity, cultus, ambiguity, folk-religion, incarnation

Hugh Mackay, an Australian novelist and social researcher, being interviewed about his book, The Good Life (Mackay 2013), described himself as a 'Christian agnostic' and said 'I suspect there are millions of us including many regular churchgoers' (Rowbotham 2013). He describes the good life as one which is ' ... characterized by goodness, a morally praiseworthy life, a life valuable for its impact on others, a life devoted to the common good' (Mackay 2013:i).

Mackay does not say in the interview that his commitment to the good life is necessarily undergirded by his 'Christian agnosticism' but the two seem to go hand in hand for many. This chapter will explore the phenomenon of Christian agnostics - that is, persons whose ethical and spiritual roots and foundations lie in the historic Christian tradition but who are agnostic about much or all of Christian dogma. It will ask whether Mackay 's assertion that there are many churchgoers who are at heart agnostic is correct, and whether this is a situation that is likely to be tenable in the long run. Is there a place and a future for persons who still hold to the centrality of Christ, or of Jesus of Nazareth, in their lives, but who are agnostic about what traditional Christianity would hold to be central points of dogma or even about the existence of what Cupitt (1984) and others have called an 'objective God'?

Martin Prozesky, in an article in the local Pietermaritzburg paper The Witness (2013), and commenting on the $50^{\text {th }}$ anniversary of the publication of John Robinson's Honest to God (1963), suggested that Robinson's belief that the church would best survive by letting go of traditional expressions of doctrine has been proved wrong. Prozesky suggests that instead, liberalism within the church has declined and authoritarian traditionalism is on the increase. 
The situation is, of course, a little more complex than Prozesky could cover in a newspaper article. Traditionalism takes a number of forms; conservative evangelicalism, which is certainly the dominant influence in the Church of England at present, and Pentecostalism, which conservative evangelicalism rejects! Prozesky is certainly correct in his view that the Christian liberalism represented by Honest to God (1963), Soundings (Vidler 1962), and The Myth of God Incarnate (Hick 1977), has waned considerably in influence and that more conservative and traditional views within Catholicism and Protestantism have become the major influences within Christianity.

Yet there are signs that this influence may be waning. While in the Roman Catholic Church the traditionalist views of Pope Benedict VI seemed to offset the advances of Vatican II, the views of Pope Francis seem to be less rigid. Within English evangelicalism voices within evangelicalism like those of Robin Parry (alias Gregory MacDonald 2008) and David Wright are questioning some aspects of evangelical thought. The considerable influence in America of conservative evangelicals like Jim Packer is being brought into question by a raft of new writers such as Clark Pinnock (1990) or Rob Bell (2011).

The waning of conservatism does not mean that liberal theology is coming back into fashion. Many people in Western Europe, Australia, New Zealand and even North America, rather than turning to traditionalism, have voted with their feet and no longer attend any church or have any links with 'organized religion' (the same may not be true of Eastern Europe or Africa for different reasons outside of the scope of this chapter).

Yet is this move away from Church the same as secularism? Are these persons now unmoved by Christian symbolism, Christian imagery, Christian liturgy, and the influence of Jesus of Nazareth? Or have they become, as Mackay describes himself, Christian agnostics? Richard Dawkins himself, aggressive and self-confident atheist as he claims to be, said in a recent Cambridge Union debate with Rowan Williams that while religion in his view was 'redundant and irrelevant' he was glad to be a 'cultural Anglican'. For those of us brought up in a Christian culture, our language moulded in that of the Bible and the Book of Common Prayer, Christian poetry, Christian art and Christian

\footnotetext{
${ }^{1}$ The Telegraph 1 February 2014. Dawkins is an English biologist, and the well-known, and controversial, author of The God Delusion (2006).
} 


\section{Ron Nicolson}

music inscribed in our memories, those echoes may still speak to our innermost being although we may find the literal dogma behind them untenable.

It is generally conceded that less people attend church services as each year goes by. A study commissioned by the Church of England noted that attendances have dropped by an average of $1 \%$ per annum since the $1930 \mathrm{~s}$ (Church Growth Research Programme 2013, drawing on Brierley 2005: 2)). Recent Church of England statistics suggest that the decline may have leveled out but the majority of those living in England do not attend church. However, a YouGov survey conducted in England in $2011^{2}$, with a representative sample size of 64000 , suggests some puzzling statistics. $70 \%$ of those polled said they had been brought up as Christians, but only 55\% described themselves as Christian now. $35 \%$ described themselves as very religious or fairly religious, and $34 \%$ said they believed in a God though only 20\% thought that God ever intervenes in the world. Only $11 \%$ said they attended a place of worship monthly or more, and $59 \%$ said they never attended. Yet $43 \%$ said that they prayed!

This suggests that a considerable proportion of those living in England (and it is likely that a fairly similar situation applies elsewhere in the 'Western' world) have a grounding in Christian belief and quite a number still see themselves as Christian, but do not attend organized worship. There are anomalies! Only $20 \%$ believe that God intervenes - but $43 \%$ pray. $35 \%$ say they are at least fairly religious but only $11 \%$ worship in church with any kind of regularity. The survey also suggests some degree of muddled thought.

We do not, of course, know what they might have meant by 'praying'. Did they mean prayer in an emergency such as the sudden diagnosis of a dread disease or prayers to assist when the car keys are unaccountably missing - or did they mean something more meditative; an occasional sense of the sacred, the transcendent, a 'Someone' or 'Something' providing an undergirding purposefulness, love, thankfulness in life. Are these 'muddled' people our Christian agnostics?

A further interesting trend is that although ordinary church attendance in the Church of England has been steadily dropping, attendance at services in English Cathedrals (i.e worshippers rather than tourists) has been steadily

2

https://yougov.polis.cam.ac.uk/sites/youngov.polis.cam.ac.uk/files/Reliigon.p $\underline{\text { df }}$ 
rising by around $3 \%$ per annum since $2000^{3}$. A columnist in the London Independent ascribes this to a desire for anonymity (or more negatively to a desire not to get involved). However, the Church Growth Research Programme suggests the reasons are more complex. Cathedral worship generally involves beautiful music in the context of uplifting buildings and art. The liturgy is often that of the Book of Common Prayer. Weekday services (which have shown the greatest increase) do not usually include sermons. Worshippers are not expected to join Bible Study groups or indeed to express their own personal beliefs at all. Could it be that the increase in attendance is because for some people cathedral-type worship offers an opportunity to be inspired by the tradition, to find the sacred, while allowing each individual to place his or her own interpretation on the words, the art, the music regardless of authoritarian church doctrine. Could many of these be 'Christian agnostics'?

James Fowler (1981) famously described what he called Stages of Faith. Building on Piaget's (1954) concept of a child passing through stages of cognitive thought from infancy until adolescence until the child is able to think logically in abstraction, Fowler suggested that in their search for meaning, people pass through a number of stages in their religious thinking, well beyond childhood and adolescence into mature adult hood. Fowler discerned seven stages, the exact details of which subsequent critics have questioned. However, essentially Fowler is describing a life-long process. While first of all, as an infant, a child develops a sense of indifferentiated trust in the world and in people, the child gradually learns the religious tradition of his family and society. Initially the child has a poor understanding of this tradition, with very anthropomorphic ideas about God. In early teenage years the tradition is held to in a very conformist way but now the young person is subconsciously aware of dissonances between the received tradition and the reality of his or her life experience. Gradually, however, at least in the ideal, the maturing person develops a view about life, morality and God which makes personal sense to him or her and which is logically coherent. Nevertheless, further maturation of thought leads to the recognition that in fact reality cannot be rendered wholly logical in such a tidy way, and there is an acknowledgement of paradox, a recognition that the concepts, images and symbols of faith are only partial. 'Truth' is complex and not susceptible to being reduced into what post modernists would call a single Grand Narrative.

${ }^{3}$ https://www.churchofengland.org/more/media-centre 
This is a somewhat simplistic summary of Fowler's thought, and it is not my concern here to judge whether Fowler is correct in perceiving these stages and in extending to adults Piaget's concepts about the development of cognitive thought in children. This has been widely debated; but the point which is of relevance to this discussion is Fowler's thesis about what he perceives as the $5^{\text {th }}$ and $6^{\text {th }}$ stages, the stage of 'conjunctive' faith, usually where the individual faces up to the contradictions and paradoxes of what he or she had previously assumed to be religious 'truth', and the stage of 'universalizing' faith in which all religions are seen to be partial expressions of a transcendent and ultimately unknowable truth in all its fullness, this being the basis for treating all people with universal principles of love and justice.

Does this mean that the mark of a religiously mature person - or in this discussion the mark of a religiously mature Christian - is that he or she recognizes that the Christian tradition is only a partial expression of truth to be seen alongside of other equally partial expressions, and that what really matters is not one's dogmatic beliefs but that one lives following universal principles of justice and peace? For many people in the post-modern world this is indeed a description of what is meant by religious maturity and comes close to the quotation from Mackay with which this chapter began. Does religious maturity mean a kind of post-modern rejection of any Grand Narrative as holding the final truth, an acceptance that there are many narratives each of equal worth (or non-worth) and that the only Grand Narrative which is of universal truth is that of the Golden Rule?

Is this a sufficient description of religious maturity? Of course a religiously mature person would be one whose life is (to quote Mackay again) '... characterized by goodness, a morally praiseworthy life, a life valuable for its impact on others, a life devoted to the common good'. But is the religiously mature person one who has outgrown the religious tradition and left it behind as just one Grand Narrative among many? Has the idea of the 'common good' become a Grand Narrative in itself? Or does the religious tradition in some way undergird and support an ethical consciousness in a unique manner?

Another writer on religious stages is Robert Ellwood, only he prefers to use the phrase 'Cycles of Faith'. His book of that title (Ellwood 2003) is largely an expansion of the book which he wrote earlier following a visit to Cape Town and Natal (Ellwood 1988). Ellwood's question is whether religion will survive, and in what form, in the future.

We live in a Western society which largely assumes that religious faith 
is generally dying. Is this in fact true? Ellwood points out that not everyone believes that the sea of faith is ebbing away, to use Cupitt's famous phrase based on the Matthew Arnold poem. Some people think that truly religious believers are just as numerous now as they ever were although more people in earlier generations may have espoused religious belief in a superficial way. Others, following the general post-Darwinian belief in evolution, believe that religious faith, too, is evolving as humans gradually become more spiritual.

Yet it cannot be denied that less people than previously feel the need for religious institutions or external religious structures. Ellwood suggests that while even 50 years ago religious leaders in Western society were seen as influential, important and on a par with persons who were important in a more secular way, this is no longer the case. Though religious belief and practice certainly continue to exist, religious institutions and religious leaders have become marginalized in that society. 'Can Christianity, or any organized religion, maintain itself in a pluralistic, computerized age', he asks (Ellwood 1988:13). Certainly evangelical Christianity and Pentecostal Christianity thrive still in other parts of the world such as sub-Saharan Africa, but is this only temporary while these cultures move from the pre-modern to the modern to the post modern?

Basing his comments on five great world religions, i.e. Buddhism, Chinese religion, Hinduism, Christianity and Islam, Ellwood suggests that most 'great religions' pass through five stages or cycles, though not simultaneously because the respective dates of the founders differ so much. Each phase lasts around five centuries.

There is the Apostolic stage, covering the lifetime of the founder and the first few generations of followers. In this stage the new religion is precarious, often persecuted, dwelling 'within the womb of an older spiritual culture' (Ellwood 1988:64). Yet the new religion, while socially and politically marginal, is quickly perceived by the growing number of followers to provide more congruency with their actual living conditions than the older culture with its gods and its ritual. The older culture slowly ebbs away as the new religion takes root.

As the number of adherents grows, we come to the Imperial stage, or the Wisdom stage. The new religion becomes the dominant religion in the society, often imposed by societal leaders. But in order to be a state religion it has to make many accommodations to meet the spiritual expectations of a wide cross-section of society and in order to be compatible with ruling philosophies. 


\section{Ron Nicolson}

Ritual, or what Ellwood calls cosmic and metaphysical world views, become more important than the historical life and teaching of the founder.

Then there is the Devotional stage. In this stage the system-making program implicit in the previous stage reaches its climax but is assimilated by the ordinary people, simplified and sentimentalized. Within Christianity Ellwood offers the example of Francis of Assisi, or the growing intense devotion during the Middle Ages to the Virgin Mary. Yet the differing personal devotional patterns and paths lay the foundation for splits which lie ahead in the next stage.

This is the stage of Reformation. The religion splits into factions. There is further simplification of the religion, but essentially the stage of reformation is a stage of reaction to a world that has changed since the foundational and imperial stages. Within the Christian tradition that meant adapting to new political realities, the rise of the middle class, the rise of nationalism. It is a turbulent and contested stage but it brings a new vitality to religion for a period.

As religion is increasingly laicized and popularized the control exercised by the religious hierarchy over the tradition and the teaching is progresssively weakened. Thus the foundations are laid for the fifth stage, that of Folk Religion. This is, in Ellwood's view, the terminal stage of a great religion, though it may continue to linger on for some centuries. Religious attitudes, practices and institutions are preserved in families and local communities but have little rapport with the major social structures (Ellwood 1988:44).

In Ellwood's view, Chinese religion and Buddhism as the older of the five Great Religions are the exemplars of folk religion, but Christianity and Hinduism are now entering that stage. Islam is many years younger and is really in the Reformation stage.

Ellwood illustrates his concept of folk religion by referring to Robert Redfield's concept of Great and Little Tradition (Redfield 1956 quoted by Ellwood 1988: 118). Great Tradition is highly literate, engaged in scriptural exegesis and interpretation, its leaders are highly educated in the same universities and to the same level as the secular societal leaders.

The Great Tradition takes a long perspective and values institutional stability. It tends in fact to emphasize the historical rather than the cosmic aspects of the religious world view, to prefer intellectual sophistication to unbridled feeling, to mistrust of charismatic 
personalities and to value interaction with the society's 'mainstream' cultural and social life. It loves excellence in religious art and architecture and those who patronize such excellence (Ellwood 1988:119).

The Little Tradition on the other hand does not greatly value the institution as such, tends to compartmentalize religion and civil society without emphasis on meshing religious views with 'mainstream' cultural life. It is mostly non-literate, centred around festivals and family ceremonies, valuing the miraculous and mystical. It takes its symbols, its stories, its festivals from the Great Tradition but without the philosophical underpinning or the firm religious hierarchy, and places its emphasis on personal devotion developed in a personal way.

Ellwood concedes that modern Christianity in its emergent folk religion form is not non-literate, but it is anti-academic. Those aspects of Christianity which are presently dominant are indicative of a move towards folk religion. 'The emergent vitality of evangelical, Pentecostal and conservative Catholic forms of Christianity and the diminishing of liberal Christianity are sure signs of the tradition's passage from Reformation to Folk Religion styles' (Ellwood 2003:146).

Folk Religion, then, according to Ellwood, is a religious style which picks stories, myths and symbols as well as festivals from the Great Tradition but is not bound by the rigidity nor the authority of the Great Tradition. It emphasizes the personal, the miraculous, the charismatic rather than the philosophical. Individuals will feel free to interpret the scriptures and the Grand Narrative in their own way, with not too much regard for logical coherence. It is consequently, as we have noted, somewhat anti-academic.

The important thing, however, about Folk Religion is that while the Great Tradition may become moribund, the Little Tradition can continue to flourish long after the Great Tradition has died. Being less interested in philosophy or academic study, and being largely on the margins of political decision making, it is more or less impervious to fashionable views of the ruling elite.

Ellwood therefore believes that the widespread belief that Western society is becoming more secular is an oversimplification. Christianity as Folk Religion will persist for a long time. It will not command respect from the ruling elite, or necessarily result in full church pews. But religious rites to 


\section{Ron Nicolson}

celebrate family occasions and rites of passage, popular religious festivals with the associated stories, belief in angels and spirit guides and the like, prayer in illness or drought or disaster, will continue for some generations at least. Television evangelists will continue to draw large audiences. Angus Buchan and preachers like him will draw crowds.

For modern popular Christianity as for folk religion, religious communication from scripture, testimony or preacher is essentially miraculous, experiential and charismatic. The words of the Bible are miracle-producing charms, not historical texts whose exegesis require persons of elite education; the revivalist or TV preacher is a shaman evoking an Other World of miracle and meaning, not a lecturer whose words require reasoned reflection (Ellwood 2003:150).

Yet we might ask, why this is the case. Why do many people still hold to religious beliefs and practices, albeit beliefs which may be a 'hodge-podge' of beliefs only loosely connected to the scholarly Christian tradition. Is it because they feel disempowered and directionless in a complex and dangerous world, or is it, as Otto famously said, that humans long for the mysterium tremendum et fascinans, the sense of something beyond ourselves which evokes awe and draws us in? We note that Ellwood mentions both 'miracle' and 'meaning'. These two words seem to me to cover two quite different concepts. Are people looking for miracles in a world where they feel disempowered and insecure? Or are they looking for a meaning beyond the immediate world of sensory and objective experience? Perhaps these are two different searches, for two different classes of person.

I want to differ somewhat from Ellwood. I recognize, as we all must, the 'Little Tradition' of which he speaks, the often inchoate, sentimental, miracle-seeking religion which picks and chooses bits and pieces from the Christian tradition with little heed to logic or congruence. Ellwood is surely right in suggesting that in this form Christian belief and practice is likely to persist for a long time, rather than the secular non-religious outlook which some have said is the future of religion. Yet in Ellwood there seems to be a certain patronization of this and of what he terms Folk Religion, a simple religion for simple people.

First of all, we must take care not to conflate evangelicalism and the kind of Folk Religion described above. Not all evangelicals are anti-academic 
or afraid of deep scholarship even though their views may not currently command respect from academic theology and philosophy. Though I do not agree with them, I would not presume to patronize Tom Wright or Alvin Plantinga, who understand theological scholarship and philosophy better than I.

Secondly, there are groups calling themselves 'Christian' which are highly literate, highly sophisticated, fully in touch with the modern world and its complexity, who can no longer ignore the dissonance between traditional theology and the modern experience of life but for whom the Christian symbols, images and rituals still speak. These are not simple people seeking a simple religion. Nor are they seeking miracles. But they are seeking meaning, and in their view the Christian tradition offers concepts and images which contribute to their search for life's deeper meaning. They do not believe some, or perhaps any, of the traditional dogmas. They are Christian agnostics.

They are indeed varied. Some attend church - like the Cathedral worshippers to whom we referred earlier in the chapter, people who find that the beauty and the imagery of Christian music, ritual and literature still speak to them of the mysterium tremendum et fascinans. They are agnostic about core Christian beliefs, but if the beliefs are taken as images, poetic attempts to encapsulate that which is beyond encapsulation then they still speak to them of the sacred.

Some have become secular Christians. Their emphasis is less on worship and the experience of the sacred in church worship but on ethics. Following Don Cupitt (1984), there is the Sea of Faith movement with its annual conferences in Britain, Australia and New Zealand. Those within the movement come from many backgrounds - Church of England vicars, Quakers, Unitarians, persons with no ecclesiastical connection but who still regard themselves as Christians. They do not believe there is a personal God, or at least are not sure that there is a personal God, but they are not 'merely' secular for the tradition still moulds them and gives shape and purpose to their longing for justice and love. Related to the Sea of Faith movement but having an independent origin there is the considerable following in New Zealand of Professor Lloyd Geering (recently made Professor Sir Lloyd Geering).

There is the Progressive Christianity movement who declare that,

By calling ourselves progressive Christians we mean that we are Christians who ... 
1. Believe that following the path and teachings of Jesus can lead to an awareness and experience of the Sacred and the Oneness and Unity of all life;

2. Affirm that the teachings of Jesus provide but one of many ways to experience the Sacredness and Oneness of life, and that we can draw from diverse sources of wisdom in our spiritual journey; ....

6. Strive for peace and justice among all people;

7. Strive to protect and restore the integrity of our Earth;

8. Commit to a path of life-long learning, compassion, and selfless love.

These movements do not seem to me to be the same as Ellwood's folk religion. They do seem to fall into the $5^{\text {th }}$ and $6^{\text {th }}$ 'stages' of religious faith that Fowler described. It is tempting to say that this is the face of religion in the future - a highly ethical world view, tolerant of differences in the perception of 'truth' yet reaching out for that sense of absolute truth of which at present we only sense as shadow. But can they last, with any connection with Christianity? Or is the search too intellectual, too cerebral, to meet the situation of most people?

I suspect this is the case. Those increased numbers attending Cathedral worship (though I number myself among them) are a small minority. Those attending Sea of Faith conferences, in my experience, are mostly middle-aged to elderly people with a background in church membership and worship, and will probably not be replaced by a younger generation without this background. In future, 'Christian' agnostics will become simply agnostics. Yet the itch, the longing, for a reality beyond the merely secular will persist. A Folk Religion version of Christianity may meet the need for many for a while. But the future shape of religion remains uncertain.

\section{References}

Bell, R. 2011. Love Wins: At the Heart of Life's Burning Questions. New York: HarperOne.

Brierley Consultancy 2005. Introduction: UK Christianity 2005 - 2015. Available at: http://www.brierleyconsultancy.com/ 
Church Growth Research Programme 2011-2013 2013. From Anecdote to Evidence: Findings from the Church Growth Research Programme 2011 2013. London: Church Commissioners.

Cupitt, D. 1984. The Sea of Faith. Cambridge: CUP.

Dawkins, R. 2006. The God Delusion. London: Bantam Press.

Ellwood, R. 1988. The History and Future of Faith. New York: Crossroad.

Ellwood, R. 2003. Cycles of Faith: The Development of the World's Religions. Oxford: Alta Mira.

Fowler, J.W. 1981. Stages of Faith: The Psychology of Human Development and the Quest for Meaning. New York: Harper and Row.

Hick, J. (ed.) 1977. The Myth of God Incarnate. London: SCM Press.

Macdonald, G. 2008. The Evangelical Universalist: The Biblical Hope that God's Love will Save us All. London: SPCK.

Mackay, H. 2013. The Good Life. Sydney: Pan Macmillan Australia.

Piaget, Jean. 1954. The Construction of Reality in the Child. New York: Basic Books.

Pinnock, C. 1990. Towards an Evangelical Theology of Religions. Journal of the Evangelical Society 33,3,September.

Prozesky, M 2013. Honest to God 50 Years Later. The Witness 30 October.

Redfield, R. 1973. Peasant Society and Culture. Chicago: Chicago University Press.

Robinson, J. 1963. Honest to God. London: SCM Press.

Rowbotham, J. 2013. 10 Questions: Hugh Mackay, Social Researcher, 75. The Australian 7 September 2013.

Vidler, A.R. 1962. Soundings: Essays Concerning Christian Understanding. Cambridge: Cambridge University Press.

Ron Nicolson Emeritus Professor Ethics University of KwaZulu-Natal Nicolson@ukzn.ac.za 